\title{
Recounting Mosque as A Center for Education of Religious Moderation \\ A Case Study of Mosque Baitul Maghfiroh in Padabenghar, Babakan Pasar, Bogor City
}

\author{
Kustini Kosasih ${ }^{1}$, Moh Zaenal Abidin Eko Putro ${ }^{2}$, \& Rahmah Nur Fitriani ${ }^{3}$ \\ (kustinikosasih20@gmail.com ${ }^{1}$,zabiep@gmail.com² ${ }^{2}$.rahmah.nf@gmail.com ${ }^{3}$ ) \\ Religious Research Development and Training Agency, Ministry of Religious Affairs ${ }^{1}$ \\ Ph.D student of the Mahidol University, Thailand ${ }^{2}$, \\ Religious Research Development and Training Agency, Ministry of Religious Affairs ${ }^{3}$
}

\begin{abstract}
Narrow mindedness in understanding religious doctrine is widely believed that is taught either intentionally or unintentionally through religious sermon and preaching. In Muslim society, such religious sermon and preaching presented normally in Islamic religious of worships including mosques. When a clergy man gives sermon to religious service event participants, it is his autonomy to speak up any ideas about Islam according to his own standpoint. In his situation, the mosque management could not control over the content of the sermon itself. This paper is based on a qualitative research to observe the implementation of non-formal education to mainstreaming moderation understanding of Islam in mosque. The sample here is purposively to attempt and to portray the religious tolerant as well as religious moderation in Baitul Maghfiroh mosque in Kampung Padabenghar, Babakan Pasar, Bogor Tengah, Bogor. The final result shows that efforts to make the mosque as a center for religious moderation through non-formal education are still limited to merely local initiatives that have not been systematically planned. In addition, the notion of religious moderation is still widely practiced merely at discourse level.
\end{abstract}

Keywords: non-formal education, religious moderation, mosque, local initiative

\section{A. Introduction}

Narrow mindedness in understanding religious doctrine is still prevalent in the mind of Indonesia' societies. One of its conditions is that one has claimed that one' own religion is better than other's. Claiming that his or her religion is better than any other religions is prone to narrow mindedness in understanding religious doctrine. Despite the Five Pillars (Pancasila) stating that humans should respect each other including religious affiliation, claiming the triumph of his or her religion is undergoing in current of Indonesia' plural society (1-3).

Engendering narrow mindedness in understanding religious doctrine is widely taught either intentionally or unintentionally through religious sermon and preaching. In Muslim society, such religious sermon and preaching presented normally in Islamic religious of worships including mosques. When a clergy man gives sermon to religious service event participants, it is his autonomy to speak up any ideas about Islam according to his own standpoint. Sometimes the mosque management could not control over the content of the 
sermon itself in this situation. An ulama, the preacher himself, has the right to tell audience about the teaching of Islam based on his exegesis on Koran and Hadiths.

However, some other ulama share their opinion on Islamic teaching wisely which is much pay attention on the contextualization of Islamic doctrine to current era. It leads to a kind of moderation in Islamic understanding. Henceforth, mosque can also be a place for promoting Islamic tolerant and moderation that avoids religious radicalism in Islam (4). Muslim should not see mosque as the beautiful physical circumstance only, but also think mosque as a social institution. Furthermore, they can learn Islamic teaching as well as Muslim society trough for example by visiting a certain mosque.

In order to make the mosque not perceived as solely the place for ritual, Indonesian government through the Ministry of Religious Affairs has issued a stipulation letter of Director General of Islamic Community Guidance (Bimbingan Masyarakat Islam) Number DJ.II/802 year 2014 about the Guidance Standard for Mosque Management. Its purpose is to provide the practical guidance for mosque managers in the area of mosque' management (idarah), mosque' operation (imarah) as well as maintenance of mosque facilities (riaayah).

Generally, to generate mosque as the center for education of Islamic moderation, some religious education activities are performed such as majelis taklim (learning Islam where teacher and student meet in informal way), study of the Koran, and special program of Islamic education for teenagers alike $(5,6)$. Here, to ascertain that mosque can be possible to spread moderation thinking in understanding Islam is very relevant to combat any other understanding of Islamic teaching that prone to be intolerant Muslim (7). It assumed that attention should be given to the mosque management officers on how they organize the religious education activities in mosque where they are mostly organized by informal way.

This paper is based on a qualitative research to observe the implementation of moderation understanding in Islam through religious education in mosque. The sample here is purposively attempted to portray and to explore the religious tolerant as well as religious moderation in Baitul Maghfiroh mosque in Kampung Padabenghar, Babakan Pasar, Bogor Tengah, Bogor. Data gathering has taken place in early July 2020 which was during the early months of pandemic covid-19.

It is widely understood that mosques have many functions. Going back to the early history of Islam, the Prophet's Mosque in Medina was not only used for obliged rituals or mahdah worship, including salat (praying). In the view of Ismail Raji al-Faruqi, an Islamic thinker who had lived in the United States, the function of mosques is diverse, among others, to solve problems of government, to arrange education, and even for military headquarters as well as prisoners of war. Here are at least 10 functions of the Prophet's Mosque recorded in history, namely (1) places of worship; (2) consultation and communication on social, economic and cultural issues; (3) education; (4) social services; (5) training and preparation of military equipment; (6) treatment of war victims; (7) peace and court to solve disputed issues; (8) receiving guests; (9) detaining prisoners; and (10) information centers (8-11).

The development of mosques in many countries, including Indonesia, has experienced with challenges to sustain the ten functions mentioned above. It is reasonable because mosque in current time is no longer representing the all ten functions mentioned above. Moreover, in general a mosque is an autonomous public space and becomes a common site that is continuously enlivened and attached to the identity and symbol of the community where the mosque is located. The variation in the structure and culture of the people in each region also bring differences to the fulfillment of the functions of the mosque.

From a political perspective, for example, the military functions of mosques in the current era will be difficult to implement considering that physical warfare is hardly occurred. In 
addition, the modern military system has separated the military from mosques. Likewise, for the function as a place for prisoners or detained war and also for court to solve disputed issues have also been drawn into the domain of the state. Even though in the decreasing function of mosques, taking an inspiration from the Prophet Muhammad' mosque is still relevant.

However, some of the old-fashioned functions of mosque that still can be seen and preserved in current era are $d a^{\prime} w a h$, social service, preserving Islamic culture and educational service. These areas are mostly in the domain of civil society realm for countries where Muslim is the majority of the population. Even, individuals of Muslim can handle the construction of mosque and its management independently, with the full support of the mosque congregation and generally without expecting support from other parties. Many mosques are of this type.

It becomes clearer here that board of management of mosque, due to their independent stand, is not easily accessible by other parties. They are independent including deciding who is eligible for giving sermon in their mosque. However, this condition also contains vulnerabilities, considering that the independence of mosque management has become an entry point of any other Islamic ideas, which endanger the mosque congregation itself. Like for example, if the teacher brings the controversial ideas of Islam, it will threaten the congregation due to the controversy of the content of the preaching.

\section{B. Literature Review: Considering Education of Religious Moderation in Mosque}

As mentioned above, mosque' function as to provide community or non-formal education is still relevant at the moment. Particularly, when seeing the fact that mosque has congregation or member, so that the mosque can educate its congregation accordingly. In fact, mosque is always present in Muslim communities and henceforth, education performed through culturally and informally approach can be held in mosque. It is because that the congregation of mosque divers in terms of ages, education level, occupation, and other similar things.

Suryono \& Tohani (2016) says that at the beginning of its development, non-formal education appeared in the term social education (Pendidikan Sosial) congruent with the term community education (Pendidikan Masyarakat) in the context of community development. Latterly, its development especially in Indonesia, social education became a Pendidikan Luar Sekolah (PLS, or out-of-school education) which was globally practiced only in Japan in the past. PLS has changed into pendidikan non formal (PNF, or non-formal education) in line with UNESCO and OECD' studies which focuses more on the context of basic education and vocational education. The term PNF itself is often found in developing countries in sort of lifelong education (12).

In developed countries, social education, out of school education, and non-formal education are less well known. Adult education and continuing education are better known in developed countries, although they are still in the same context as lifelong education. Then, the development of non-formal education began in the early 1970s in the form of literacy education for basic and skills education in the form of vocational education in the community. It is in the frame of lifelong education which is to build society becoming into a learning society.

Taking this kind of understanding, non-formal education is potentially developed in mosques, including to promote religious moderation. Non formal education for religious moderation has become an opportunity to be disseminated to the wider community in a non-formal way. It can also be carried out by andragogical way in which relies on an adult education approach. The issue of moderation of religion in mosque will be very significant when using this kind of nonformal education, like for example through recitation of Quran, lectures, halaqoh studies and 
other similar things.

Regarding with the word of what so-called moderate, this paper put emphasize on the definition of moderate that was formulated by the Indonesian Ministry of Religion. According to it, moderation in religion does not mean compromising the different basic principles and different main religious rituals in order to please others who have a different religious understanding and a different religion as well. Religious moderation is also not meant for not taking someone' own religious teachings seriously. On the contrary, being moderate in religion means being confident in the essence of the teachings of the religion he or she adheres to, while he or she shares the truth as far as religious interpretation is concerned. The character of religious moderation requires openness, acceptance, and cooperation of each different group. Therefore, every individual adherent to religion must be willing to listen to one another regardless of ethnicity, culture, religion, and political choices and to learn from each other in order to train the ability to manage and overcome differences in religious understanding between them (13).

Take an analogy, moderation is like movement from the edge position which always tends to move toward the center or axis (centripetal), while extremism is the reverse movement away from the center or axis, towards the outermost (centrifugal). Just like a pendulum clock, there is a dynamic motion, not stopping at one extreme outside, but moving toward the middle. To borrow this analogy, in the context of religion, moderate attitudes are thus the choice to have perspectives, attitudes, and behaviors in the middle position among existing extreme choices. Whereas, religious extremism is a viewpoint, attitude, and behavior that exceeds the limits of moderation in understanding and practicing religion. Therefore, religious moderation can then be understood as a perspective, attitude and behavior that always takes a position in the middle, acts fairly, and is not extreme in religion (13).

Previous study on mainstreaming of religious moderation in mosque was done by many scholars including Muktafi (2018), Sumarto (2019) dan Darodjat (2014) (14-16). These articles mainly describe the fact that how board of management promoting religious moderation by for example thoroughly selecting a cleric who will be invited to give sermon. Besides, the mosque management also determined the themes that the invited cleric should remark. As a result, the mosque keeps continue to prevent from infiltration of Islamic teaching that bring about radicalism.

Therefore, religious moderation must be understood as a balanced religious attitude between the practice of one's own religion and respect for others. This balance or middle way between religious practice and religious understanding will undoubtedly prevent us from excessive extremes, fanatics and revolutionary attitudes in religion. As indicated earlier, religious moderation is a solution to the presence of two-sided coin extremism in religion, the ultra-conservative or right-wing poles on the one hand, and the liberal or left-extreme on another hand.

As a result, according to Woodward (2015), the process of Islamization in Indonesia is not of a radical nature, but it is resulting in more Islamic focused public discourse and governing policy. The recent addition of civic education in Islamic schools, which has been exalted by Westerns, is taught with specific Islamic interpretations that change the meaning of concepts, particularly pluralism. The resulting consequence is that while Islam and democracy's compatibility are stressed in Islamic civic education, however tolerance for pluralism is need to be questioned (17). 


\section{Research Method}

This paper is based on a qualitative research that aims at gaining understanding and having depth information from the subjects that are being studied. In this case, the research reached out some informants especially those who involved in the Baitul Maghfiroh Mosque in Padabenghar, Babakan Pasar Village, Central Bogor District, Bogor Municipality. Some informants that were interviewed by the authors including, but not limited to, the head, the secretary, the treasure as well as the advisor of mosque board management. The authors also interviewed some member of mosque congregation.

To explore data, this study used three different data gathering techniques, namely, observation, in-depth interviews and document study. In-depth interviews were conducted with the member of Dewan Kemakmuran Masjid (DKM, or board of mosque management) of Baitul Maghfiroh Mosque as it is mentioned above. Observations were made by directly visiting the subject as well as the site or research location for several times. Whereas, the document study was carried out by reading some articles, documents and books as well regarding with the topic.

\section{Research Results and Discussion}

The city of Bogor was formerly known as Pakuan, the capital of the Pajajaran Kingdom. Its anniversary is commemorated every June 3 which is rooted at the crowning of King Siliwangi on June 3,1482. Physical symbol of this city is Kujang, a typical traditional weapon of the Pajajaran Kingdom. Now, some statues of kujang can be seen at certain areas of Bogor city. One of its largest statues is located on Pajajaran street.

Bogor (it is assumed from Dutch term, Buitenzorg) was used as the capital of the Dutch East Indies colonial government, particularly when Governor General Van Alting (1780) took a power. The city was originally functioned as center to monitor and cultivate high valued plantation by landlords. Moreover, the plantation in Bogor area was at its heyday after this city was being connected to Jalan Raya Pos (Groote Postweg). The road itself was built starting in 1811 by Daendels and later by railroad (Batavia-Buitenzorg) in 1873. The city's physical artifacts built during the colonial era are still quite well recognized, one of which is the Bogor Palace (formerly known as the Buitenzorg villa) which was founded on the initiative of the Governor General GW Baron van Imhoff. This building also served as the office of the Governor General of the VOC and the Governor-General of the Dutch East Indies until it was finally used as the Presidential Palace of the Republic of Indonesia. As we can see currently, the courtyard of the Buitenzorg palace functioned as a Botanical Garden by a German botanist, Prof. R.C. Reinwardth and inaugurated as Bogor Botanical Gardens in 1887 (18).

Bogor City has 11,850 hectares which is divided into 6 sub-districts and 68 urban villages. The six (6) districts are namely South Bogor District, East Bogor District, North Bogor District, Central Bogor District, West Bogor District and Tanah Sereal District. The Bogor City area is surrounded by areas in Bogor Regency (Kabupaten Bogor) with their respective borders. The western most is next to Darmaga and Ciomas sub districts, the eastern most region is next to Sukaraja and Ciawi sub district, the northern most region is next to Kemang, Bojong Gede and Sukaraja Subdistrict, whereas the southernmost region is next to Cijecuk and Caringin subdistrict (19).

According to Bogor City statistical agency data, the population of Bogor city has been growing rapidly. In 2010 , its total population was 958,114 . Then, it raised to $1,064,687$ people 
and in 2017 recorded temporary 1,081,009 people. The mean of population growing is 1,53 percent. Furthermore, Bogor city is a densely populated area. Viewing slightly on each of its subdistrict, Bogor Tengah subdistrict has the most densely populated subdistrict that is 12,897 per kilometers square. Then, Bogor selatan subdistrict has 6,544 people per kilometers square, Bogor Timur subdistrict has 10,446 people per square, Bogor Utara subdistrict has 11,064 people per kilometers square, and Bogor Barat subdistrict records 7,302 people per Kilometers square. Finally, Tanah Sareal subdistrict has 12,346 people per kilometers square. Whereas M uslim population in Bogor City reaches 994,616 out of a total population of 1,064,687 people. It means that the Muslim population in Bogor city equals to 94 percent of the total population. Meanwhile, the number of mosques in Bogor city is 762 mosques (19).

Economically, the rate of economic growth continues to raise. It can be seen from the data of Gross Regional Domestic Product (GRDP) per capita in Bogor city 2011-2017 that drew at the book entitled Bogor in Number (Bogor Dalam Angka), published by BPS Bogor city 2018. In 2013, GDRP was IDR 22,20 million in average with its growth was 4,16 percent. Whereas in 2014, it increases to IDR 23,12 million, with the growth rate was 4,19 percent (19).

\section{D.1. The Establishment History of Baitul Maghfiroh Mosque, Babakan Pasar, Bogor City}

It is about 2 kilometers from the Bogor Grand Mosque or, one kilometer from Bogor Botanical Garden, we can find Chinatown area of Bogor City where the Baitul Maghfiroh Mosque was established. This mosque is surrounded by a densely populated area, a typical of slum and old town area. Getting to this mosque is more convenient to walk than to use any other vehicles. It can be entered from Roda street, or from Suryakencana street, where one can across this street from Bogor Botanical Garden (Kebon Raya Bogor). Hearing the name of this street, namely Suryakencana street, it is certainly true to remind readers of the culinary center of Bogor City. Besides, this road is also the gateway to the Chinatown village designed by the Dutch colonial government. Therefore, the historical content is very strong.

What do the authors mean is related to the colonial-style racism' policy. The colonial government divided the residential location of Bogor City at that time into three different enclaves, namely European enclaves whose traces can now be found around Kebon Raya, namely Juanda street and its surroundings, then Kampung Chinatown which is now in Babakan Pasar Village or Suryakencana street, flanked by Ciliwung and Cipakancilan River, together with Arab descendant. The rest was indigenous villages that its footstep can be found in the Sukahati area.

When visiting this mosque for the first time, on July 2, 2020, the authors met the head of the mosque' management board, namely Ikhwan Tirtana, who works at the Dinas Pemadaman Kebarakaran (Damkar, or Bogor City Fire Service). At the time, he was accompanied by several important figures in this mosque, including the mosque's imam, Muhtarom, who was also the founder of this mosque, Cecep who is the treasure of mosque management and Dudun who is the general affairs manager of the mosque.

It is stated that the land where the mosque was built was owned by a Chinese descendant named Edi Chafik who had become a Muslim convert. The land area should have been around 300 square meters, but not all of the land was owned by the mosque because several meters were still controlled by local residents. This area used to be the location of a soap factory 
and the mosque around this area used to be a mess for the soap factory employees. Such rapid urban changes, along with the high cost of living in Bogor city, have made land so valuable here (anonymous informant, 3 July 2020). Furthermore, the population is getting much denser. In the end, the occupancy became crowded and the road to the mosque is only a small alley.

The current feature of mosque was built form from 2005 to 2007 with initial funds from local community organizations, even though the committee took a kenclengan (public donation boxes) on Suryakencana street. Some rich Muslim also donated their fund individually. Currently, local resources to operate the mosque are more empowered, ranging from imams to lead salat to Friday preachers. The mosque employs 8 cleaning service staff (marbot) with monthly routine expenses for the entire staff totaling IDR. 1.2 million. This amount of funds is divided evenly for all the staff with the amount received by each staff is not the same. Routine funds to mosque are obtained from mosque donations every Friday that around IDR 300 hundred thousand (interview the authors with Cecep, the treasure of the mosque, 2 July 2020). In terms of organization, this mosque takes supervision of the Dewan Masjid Indonesia (DMI, or Indonesian Mosque House) Bogor City (interview the authors with Ikhan Tirtana, the head of mosque management, 2 July 2020). DMI is a national flagship organization that has branches in many cities in Indonesia.

The selection mechanism to elect board management member in this mosque is that they are appointed by the community's elders, whose election is based on deliberation as well as based on the people's judgment. Therefore, this election actually involves all citizens. Once the agreement was made, a new board management member name list then sent to DMI Bogor city in order to get its stipulation letter (interview the authors with Dudung, a mosque manager, 5 July 2020).

\section{D.2. Education of Moderation in Baitul Maghfiroh Mosque}

As it has mentioned above, this mosque was built by community self-effort, henceforth this mosque is owned by the local community. In this regard, the way they ascertain the level of religious moderation at their mosque is carried out by selectively using the services of preachers from outside the community. Indeed, their moderation is implemented by limiting the influence of outside ideas by maximizing resource person in the community around the mosque. Only in certain situations, mosques invite preachers from outside Padabenghar village and its surroundings, for example the Ikhya Council (Majelis Ikhya) from outside the subdistrict. The limitation of outsiders in contributing religious services in this mosque is the way this mosque deterring it from the influence of understandings that are considered incompatible with government policy. They themselves do not want their mosque is being supervised by outsiders which previously unknown of their Islamic teaching background.

The main figure who is considered as a charismatic leader in this mosque is Juwaini, a former member of the Bogor house of representative. He is an alumnus of an Islamic boarding school (pesantren), and graduated from Ibnu Khaldun University (UIK), a well-known Islamic campus in Bogor. This cleric has written some his own lecture materials in pegon letters which was flavored with verses from the Koran and hadith. Now, his age is more than 70 years old.

"Pak Haji Juwaeni, who we consider a scholarly figure we refer to in every way, has chosen an imam / khatib on his recommendation. He is also our teacher at every Thursday night study. He is one of the community figures here. He used to be a member of Bogor Indonesian Council of Ulema (MUI, Majelis Ulama Indonesia) who is also 
living nearby. We afraid that his age is over 70 years old and in a state of illness. He is the only Islamic scholar here. We have been worried because of his illness. It is also about Ustadz Muhtarom. Both are our respected teachers. Of course, it is like of what so-called a yellow light for us, because there is no young teacher yet to be prepared to substitute them." (interview the authors with Dudun, mosque manager, 4 July 2020)

Learning Islamic teaching for certain topics in this mosque has always been requested by members of the mosque congregation. Once the congregation asked this week for this material (figh, for example), they were asked to wait first. If the previous material from A-Z has not been completed, it will continue to be discussed until it's finished, then move on to another new material. In addition, unfortunately, so far there has been no special learning on the $\mathrm{Al}$ Qur'an. They have been taught by only regular recitation every Wednesday night and Saturday night. Currently, they plan to call a special teacher to teach the Al Quran (Interview with Dudung, 5 July 2020 dan).

However, in relation to strengthening religious moderation, the management of the Baitul Maghfiroh Mosque, such as the secretary Hendy and the Advisor Zainal Abidin, admitted that they had never collaborated with non-Muslims. This needs to be considered important because this mosque is located not far away from the Chinatown village where the Buddhist monastery can be found. In fact, as mentioned above, not far away from this mosque, there is a Chinese community who adhere to religions other than Islam. In certain Chinese events such as Chinese New Year and Cap Go Meh, the non-Muslim Chinese people prefer neighborhood (RT and RW) officials to cooperate, in the form of distributing aid coupons for instance. The board of mosque management has never been involved, although in practice the coupons were distributed to the congregation of the Baitul Maghfiroh mosque. In fact, at the time of Cap Go Meh, many Muslims (wearing headscarves for women Muslim) join donations distribution by queuing at the monastery yard. Likewise, at the time of distribution of groceries in the month of Ramadan, the place of distribution is in the monastery and not in this mosque. This features are quite disturbing for them (Interview, 5 July 2020)

This feature makes unpleasant for some Baitul Maghfiroh mosque administrators absolutely. But, what can they do if not far away from this mosque is made a cultural heritage area and cultural tourism by the local government?

"Never mind with the local people, even the mayor Bogor city himself introduced the Chinese culture as the city' heritage. He said that Chinese heritage is a cultural element of Bogor community. Here, we don't want to question about ethnicity, but indeed our natives those who sell in the market have been marginalized since the mayor's decision on urban planning that emphasizes their (Chinese) ethnicity, including the existence of red lanterns in the alleys and so on. Even though we are the citizen of Bogor city which is also famous for its pasundan. When it comes to politics, it is feared that sooner or later, Bogor will be controlled by non-Muslims. Surprisingly, the MUI and Bogor DPRD member just kept quiet. We are sad at the current condition; they control over economic sector." (Interview the authors with anonymous member of Baitul Maghfiroh mosque' board of management, 5 July 2020).

In general, at the level of faith and religious doctrine, the management board of the mosque and its member have never cooperated with non-Muslim Chinese. Even, a hidden contestation and suspicion persists as mentioned above. But, on the daily basis of economy ( muamalah) level, they keep trying to cooperate as much as they can. Like for example in terms of commerce in the market. Likewise, in the casual affairs of everyday life. In fact, they are 
astonished because their non-Muslim Chinese neighbor can easily pronounce Islamic words such as hamdalah (alhamdulillah), insha Allah and so on to the Muslims when both side in a conversation, while their fellow neighbors actually still believe in non-Muslim faiths. This is why they still respect non-Muslim around the mosque and away from displeasure among local Muslims (interview with Hendy, the secretary of Baitul Maghfiroh mosque, 5 July 2020).

As mentioned above, it should be noted here that in deepest hearts of some Baitul Maghfiroh mosque administrators, they really objected to the proclaiming of cultural heritage arranged by the Bogor City Government which in fact paying more attention to their fellow' culture and conversely marginalized local culture, namely Sundanese of Bogor. They do not dare to speak frankly, because the Bogor government under Mayor Bima Arya has enforced cultural heritage in the surrounding areas, such as in Pulo Geulis village which is not far from this mosque.

\section{E. Community Education for Religious Moderation; A Local Initiative and A Discourse}

The concept of religious moderation that was formulated by the Indonesian Ministry of Religion is that moderation in religion does not mean compromising the different basic principles and different main religious rituals in order to please others who have a different religious understanding and a different religion as well. Furthermore, religious moderation is also not meant for not taking someone' own religious teachings seriously. On the contrary, being moderate in religion means being confident in the essence of the teachings of the religion he or she adheres to, which teaches fair and balanced principles while he or she shares the truth as far as religious interpretation is concerned. In addition, the character of religious moderation requires openness, acceptance, and cooperation of each different group. Therefore, every individual adherent to religion must be willing to listen to one another regardless of ethnicity, culture, religion, and political choices and to learn from each other in order to train the ability to manage and overcome differences in religious understanding between them. This basic principle of religious moderation is potentially promoted through non formal education in mosque.

To assure the moderation in understanding Islamic teaching, the board of management of Baitul Maghfiroh mosque request Dewan Masjid Indonesia (DMI, or Indonesian Mosque Council) to supervise their management system as well as their Islamic teaching. Because it is a community-based mosque, they relatively independent to choose preachers to give religious remarks. Put in this way, the way they ascertain the level of religious moderation at their mosque is carried out by selectively using the services of preachers from outside the community. However, spreading Islamic moderation teaching is still not well established and systematically arranged. Religious moderation on community-based education is also still being planned but has not implemented yet.

Regarding with non-formal education, Suryono \& Tohani (12) says that at the beginning of its development, non-formal education appeared in the term social education ( Pendidikan Sosial) congruent with the term community education (Pendidikan Masyarakat) in the context of community development. Then, the authors try to analyze the practice of nonformal education of religious moderation based on the data described above.

The authors see that the function of mosques as non-formal education to promote moderation in Baitul Maghfroh mosque that is examined in this paper is not implemented in a clear and distinct manner, but is implicitly practiced by mosque administrators to keep their mosques from being entered by other religious understandings that are different from their understanding. Only in 
certain situations, mosques invite preachers from outside Padabenghar village and its surroundings. The limitation of outsiders to perform of religious moments in this mosque is the way in which this mosque fortifies it from the influence of understandings that are considered incompatible with government lines.

Henceforth, efforts to make the mosque a center for religious moderation education in this mosque are still limited to local initiatives that have not been planned systematically. In addition, the notion of religious moderation is still widely practiced at the discourse level. They agree that Muslim should respect to other fellows non-Muslim. However, when they asked for being collaborated much more with their fellow non-Muslim, they still do not want to do that. In fact, the mosque management and congregation have never collaborated with non-Muslim Chinese in the vicinity of the mosque area for instance.

In this regard, the authors agree with Woodward' statement above that religious toleration in Indonesia is still need to be improved. Moderation and toleration practiced in mosque should be in line with the concept of respect to other religious people, respect to human dignity, and reverence to local culture as well. Moderation in Islam should not be only in a matter of concept that has never been implemented. Religious leader as well as the government should encourage Indonesian Muslim, including the congregation of this mosque, to begin with the implementation of religious moderation in their daily life.

\section{F. Conclusion}

The function of mosques as non-formal education to promote moderation in mosques that is examined in this paper is not implemented in a clear and distinct manner, but is implicitly practiced by mosque administrators to keep their mosques from being entered by other religious understandings that are different from their understanding. Whereas, the function of the mosque as a place for non-formal religious moderation education is implemented indirectly by maximizing the human resources in the area around the mosque. Only in certain situations, mosques invite preachers from outside Padabenghar village and its surroundings. The limitation of outsiders to perform of religious moments in this mosque is the way in which this mosque fortifies it from the influence of understandings that are considered incompatible with government lines.

However, efforts to make the mosque a center for religious moderation education in this mosque are still limited to local initiatives that have not been planned systematically. To promote religious moderation through community based-education is still unclear. In addition, the notion of religious moderation is still widely practiced at the discourse level. The mosque management and congregation have never collaborated with non-Muslim Chinese in the vicinity of the mosque area for instance. Religious leader as well as the government should encourage Indonesian Muslim to begin with the implementation of religious moderation in their daily life.

\section{Reference}

ADDIN Mendeley Bibliography CSL_BIBLIOGRAPHY $1 . \quad$ Winarni LN. the Existence of Pancasila in Facing Threats. 2020;8(1):90-6.

2. GUNAWAN B, RATMONO BM. Threats to the Ideology of Pancasila In the Reform Era: Praxis Case of Regional Development Policy. J Stud Pemerintah. 2018;9(1).

3. Sudjito S, Muhaimin H. Membudayakan Nilai-Nilai Pancasila Dan Upaya Menangkal Tumbuhnya Radikalisme Di Indonesia. WASKITA J Pendidik Nilai dan Pembang Karakter. 2018;2(1):1-16. 
4. Kustini K, Eko Putro ZA. DAKWAH ACTIVITIES AMONG MUSLIM MINORITY AND THE PREVENTION OF HATE SPEECH IN KUPANG, EAST NUSA TENGGARA. Anal J Soc Sci Relig. 2017;

5. Mustofa AK, Muhyiddin A, Nase N. Manajemen Majelis Taklim dalam Meningkatkan Fungsi Masjid. Tadbir J Manaj Dakwah. 2017;2(1):1-17.

6. Mustofa MA. Majelis Ta'lim Sebagai Alternatif Pusat Pendidikan Islam (Studi Kasus pada Majelis Ta'lim Se Kecamatan Natar Lampung Selatan) Muhamad. J Kaji Keislam dan Kemasyarakatan. 2016;1(01):1-18.

7. Kurniawan A. Peran Masjid sebagai Sentra Dakwah Moderasi. J Komun Islam. 2020;10(2).

8. Dalmeri D. Revitalisasi Fungsi Masjid sebagai Pusat Ekonomi dan Dakwah Multikultural. Walisongo J Penelit Sos Keagamaan [Internet]. 2014;22(2):321-50. Available from: http://journal.walisongo.ac.id/index.php/walisongo/article/view/269

9. Jannah N. Revitalisasi Masjid Di Era Modern (Studi Terhadap Peranannya Di Era Modern). J Anal Islam. 2016;5(1):125-48.

10. Suryani H, Faizah SI. Peran Masjid Sebagai Roda Penggerak Perekonomian Masyarakat (Penelitian Deskriptif Pada PKL di Kawasan Masjid Al-Akbar Surabaya). J Ekon Syariah Teor dan Terap. 2015;2(5):387.

11. Mawardi I, Baihaqi A, Subur, Sari KP. A Model of Friendly and Tolerant Community-Based School Mosque Management: Strategy Analysis and Empowerment. 2020;436:742-6.

12. Suryono Y; Tohani E. Inovasi Pendidikan Nonformal. 2016;200. Available from: http://staffnew.uny.ac.id/upload/130799881/pendidikan/Inovasi Pendidikan Nonformal.pdf

13. RI TPKA. Moderasi Beragama. Badan Litbang dan Diklat Kementerian Agama RI; 2019.

14. Muktafi. DINAMIKA PENGARUSUTAMAAN MODERASI ISLAM DI MASJID NASIONAL AL -AKBAR SURABAYA ( MAS ). Islam Insid J Keislam dan Hum. 2018;4(1):121-53.

15. Sumarto $\mathrm{S}$. Constitutional protection of religious freedom and belief for indigenous peoples in indonesia. 2017;12(4):11-2.

16. Darodjat, Wahyudhiana. Memfungsikan Masjid Sebagai Pusat Pendidikan Untuk Membentuk Peradaban Islam. Islam J Pemikir Islam [Internet]. 2014;13(2):1-13. Available from: http://jurnalnasional.ump.ac.id/index.php/ISLAMADINA/article/view/1675/1419\%0Ahttp://jurnalna sional.ump.ac.id/index.php/ISLAMADINA/article/view/1675

17. Woodward K. Indonesian Schools: Shaping the Future of Islam and Democracy in a Democratic Muslim Country. J Int Educ Leadersh. 2015;5(1).

18. Tohjiwa AD, Soetomo S, Sjahbana JA, Purwanto E. Kota Bogor dalam Tarik Menarik Kekuatan Lokal dan Regional. Semin Nas Ris Arsit dan Perenc 1 HUMANISME, Arsit DAN Perenc. 2010;

19. Badan Pusat Statistik Kota Bogor. Kota Bogor dalam Angka Bogor City in Figures 2018. 2018;1(2):1-416. 